\title{
SOIL NUTRIENTS AND VEGETATION STRUCTURE IN A NEOTROPICAL SEASONAL WETLAND
}

\author{
MACHADO, N. G. ${ }^{* 1,2}$-SANCHES, L. ${ }^{2}-$ Silva, L. B. ${ }^{2}$ - NOVAIS, J. W. Z. ${ }^{3}-$ AQUinO, A. M. ${ }^{2}-$ \\ BIUdES, M. S. ${ }^{2}-$ PinTO-JUNIOR, O. B. ${ }^{2}-$ NOGUEIRA, J. S. ${ }^{2}$ \\ ${ }^{1}$ Laboratório de Biologia da Conservação, Instituto Federal de Mato Grosso, Cuiabá, Mato \\ Grosso, Brazil \\ ${ }^{2}$ Programa de Pós-Graduação em Física Ambiental, Universidade Federal de Mato Grosso, \\ Cuiabá, Mato Grosso, Brazil \\ ${ }^{3}$ Programa de Pós-Graduação em Ciências Ambientais, Universidade de Cuiabá, Cuiabá, Mato \\ Grosso, Brazil \\ *Corresponding author \\ e-mail:nadja.machado@blv.ifmt.edu.br \\ (Received $9^{\text {th }}$ July 2014; accepted $14^{\text {th }}$ Aug 2014)
}

\begin{abstract}
The Pantanal is a large and diverse wetland whose main attribute is the flood pulse that alters soil nutrients and contributes to spread an invasive tree (Vochysia divergens Pohl) for more than four decades forming monospecific stands (locally known as Cambarazal). Our goal was to investigate soil nutrients and vegetation structure in a seasonal flooded forest dominated by Vochysia divergens Pohl in the Northern Brazilian Pantanal. There was an increasing of $\mathrm{H}+\mathrm{Al}, \mathrm{H}, \mathrm{OM}, \mathrm{S}, \mathrm{P}, \mathrm{Al}$ and $\mathrm{CEC}$ concentration after flooding, but only Fe showed a significant increasing. There was a decreasing of $\mathrm{pH}$, $\mathrm{Cu}, \mathrm{Zn}, \mathrm{Mg}, \mathrm{Ca}+\mathrm{Mg}$ and sand values after flooding, but only values of $\mathrm{Mn}$, clay and silt showed a significant decreasing. There was no variation in concentration of B and $\mathrm{K}$ after flooding. We found 14 species distributed in 13 families. V. divergens had the highest abundance followed by L. parvifolia and M. elliptica. The mean diameter was $28.36 \mathrm{~cm}$, density was 839.98 individuals.ha $^{-1}$, and average basal area was $66.16 \mathrm{~m}^{2}$.ha ${ }^{-1}$. The plant community had a negative diameter distribution while $V$. divergens population had a Gaussian distribution. The diversity was higher with less $V$. divergens dominance. Thus, flooding affected soil nutrients and dominance of invasive species affected species distribution and diversity in a Neotropical seasonal wetland.
\end{abstract}

Keywords: nutrient storage; Cambará; invasive species; self-thinning rule; diameter distribution.

\section{Introduction}

Wetlands are a complex aquatic-terrestrial transition zones along the periodically floodplains (Junk et al., 1989). These areas can strongly influence local and regional climates through their dynamic interactions with the atmosphere (Ehhalt et al., 2001). Pantanal is the largest seasonally flooded plain of the world, located in the center of South America (Junk et al., 2006; Zeilhofer, 2006), occupying a surface area of approximately $150,000 \mathrm{~km}^{2}$ which spans Brazil, Paraguay, and Bolivia (Haase, 1999). The main attribute is the flood pulse (water level variation) that regulates its ecological processes (Junk et al., 1989).

Flooding causes physical, chemical and biological changes in soils (Pezeshki and Delaune, 2012), suffering several cycles of alternating aerobic and anaerobic conditions (Reddy and Patrick, 1975), and affecting processes in the soil such as reduction in soil redox potential, $\mathrm{pH}$, iron, manganese and sulfate, and nitrification (Ponnamperuma, 1972; Reddy and Patrick, 1975; Kirk 2004; Pezeshki and Delaune, 2012). These changes can interfere in the nutrient availability and production of toxic substances 
(Ponnamperuma, 1972; Kirk, 2004). In general, the nutrient concentration shows an initial increase followed by a decrease, and a subsequent stabilization, which is affected by flooding duration (Ponnamperuma, 1972; Souza, 2001; Lima et al., 2005).

The Pantanal is considered to be extremely diverse, with approximately 144 families of higher plants and more than 1,000 plant species (Junk and Nunes da Cunha, 2005). The topographical variations and differences in local flooding (intensity and duration) model the landscape and distribution of vegetation types (Neiff 1990, 2001; Nunes da Cunha et al., 2007), once engaged in the distribution and abundance of plants (Nunes da Cunha and Junk, 2001; Zeilhofer and Schessl, 2000; Rebellato and Nunes da Cunha, 2005; Damasceno-Jr et al., 2005; Arieira and Nunes da Cunha, 2006). Plants face conditions of extreme water stress either by the lack of or the excess of water (Junk and da Silva, 1999). These conditions favor the persistence of large numbers of pioneer species in the Pantanal, keeping their populations at high densities (Pott and Pott, 1994; Silva et al., 2000), forming monospecific stands such as Vochysia divergens Pohl, Tabebuia aurea Benth. \& Hook.f. ex Moore, and Copernicia alba Morong, (Nunes da Cunha et al., 2007). Only 5\% of tree species live exclusively in prolonged flooding areas, $30 \%$ are restricted to areas rarely flooded and $65 \%$ are widely distributed in the flooding gradient in the Pantanal (Nunes da Cunha and Junk, 1999).

However, this biodiversity is vulnerable because of land use practices, changes in hydrology and climate, and invasive species (Junk et al., 2006). In terms of invasive species, the spread of Vochysia divergens Pohl (commonly known as Cambará) in the Pantanal is a well-documented example (Vourlitis et al., 2011). By the other hand, the reason for the invasion is still poorly understood; however, interactions between flooding, soil properties, and fire appear to be critical for invasion success (Zeilhofer and Schessl, 1999; Nunes da Cunha and Junk, 2004). This species is a native tree of the Brazilian savanna (Cerrado) and riparian forest (Lorenzi, 2002), and is a flood-adapted pioneer species that has been vigorously spreading into seasonally flooded native grassland for more than four decades (Nunes da Cunha and Junk, 2004). V. divergens can grow to heights of 28 to $30 \mathrm{~m}$ and has a dense leafy crown that effectively shadesout grasses, forbs, and trees, forming dense, species-poor stands known as Cambarazal (Nunes da Cunha and Junk, 2004).

Given the potential effects of flooding on soil properties, and the rapid and extensive spread of Cambará, our goal was to investigate soil nutrients and vegetation structure in a seasonal flooded forest dominated by Vochysia divergens Pohl in the Northern Brazilian Pantanal.

\section{Material and Methods}

\section{Study area}

The study was conducted in a flooded forest at Parque Baía das Pedras (16 $43^{\circ}$ '51'S: 56 04'17'W) of the Estância Ecológica SESC Pantanal in the Northern Brazilian Pantanal, which is located 130 km SSW from Cuiabá, Mato Grosso, Brazil. (Figure 1). The regional climate according to Köeppen classification is Aw, which represents a hot and wet climate with rainfall in the summer and drought in the winter. Annual rainfall is on average $1400 \mathrm{~mm}$ with a pronounced dry season from May through September (Nunes da Cunha and Junk, 2001). The annual average of air temperature oscillates between a maximum from 29 to $32^{\circ} \mathrm{C}$ and a minimum from 17 to $20^{\circ} \mathrm{C}$ (Brasil 1997; Biudes et al., 2013). The topography is virtually flat, causing extensive flooding during 
the wet season (Fantim-Cruz et al., 2010). The soils are from sedimentary origin, occurring in clayey and sandy phases alternately and discontinuously with the dominance of hydromorphic soils (Amaral Filho, 1984).
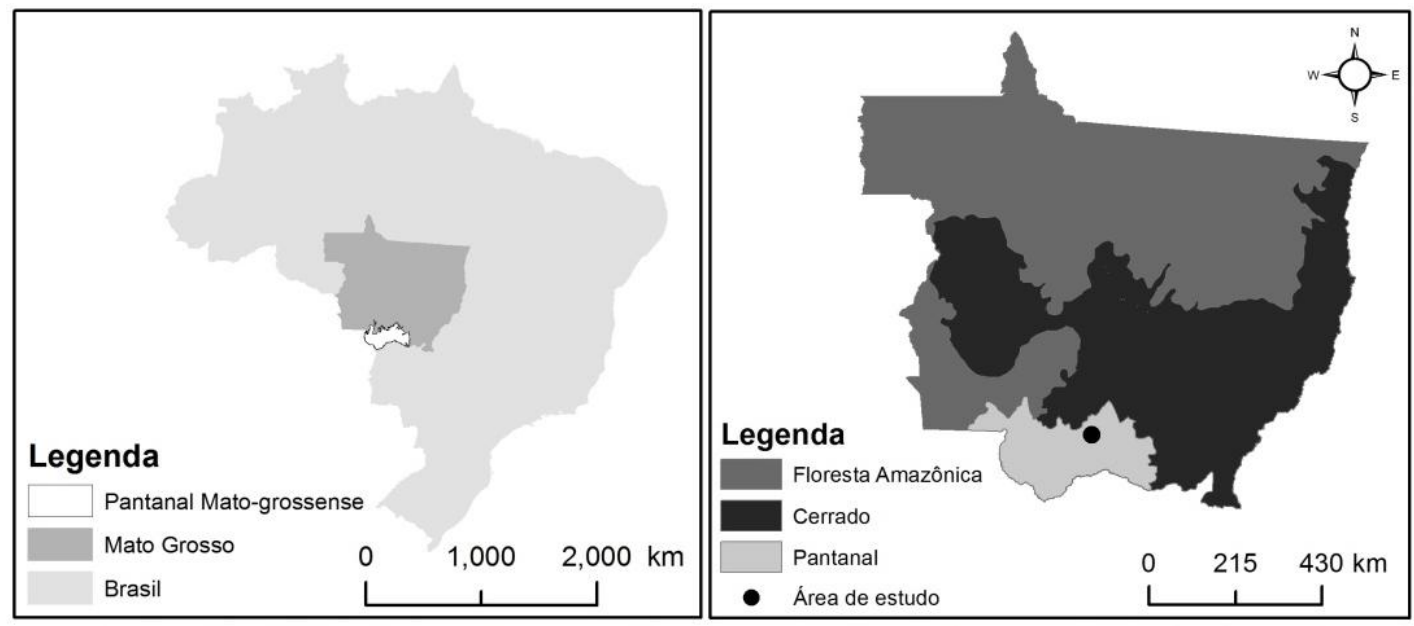

Figure 1. Location of study area in the Northern Brazilian Pantanal.

\section{Field Measurements}

Five transects of 50 meters each one were established in study area with sampling points at intervals of $5 \mathrm{~m}$ in the study area. Micrometeorological variables were collected over one year (January-December 2012). The water level was measured by a graduated tape in 55 sampling points, once a month during the flooding period in 2012. The soil water content was measured at the 0-12 cm layer using a portable TDR sensor (Hidrossense II Mod CS620, Campbell Sci., USA). Soil was sampled from each point from the upper $10 \mathrm{~cm}$ soil layer using a hammer core in December 2011 (before flooding) and July 2012 (after flooding).

Species were sampled in transects using the point-quarter method (Goldsmith and Harrison, 1976). Briefly, each measurement point was divided into four quadrants, and within each quadrant, the distance to the nearest tree and its circumference greater than $20 \mathrm{~cm}$ at breast height ( $1.3 \mathrm{~m}$ aboveground) were measured. All sampled trees were identified and marked with plastic numbered plates for purposes of long-term monitoring. In case of trees with multiple stems, each one was separately measured, and the sum of their areas was considered the basal area of the tree.

\section{Micrometeorological variables}

One micrometeorological station (model WXT520, Vaisala Inc., Helsinki, Finland) was installed at $2 \mathrm{~km}$ south of study area. The collected variables were: air temperature $\left({ }^{\circ} \mathrm{C}\right)$, relative humidity $(\%)$ and precipitation $(\mathrm{mm})$. The data were stored at intervals of 30 minutes in a datalogger (model CR1000, Campbell Scientific, Logan, Utah, USA), connected in a battery with solar panel.

The vapor pressure deficit (VPD) in $\mathrm{kPa}$ was calculated by:

$$
\mathrm{VPD}=e s-e a
$$

where es is the saturation vapor pressure, and ea is the actual vapor pressure $(\mathrm{kPa})$. 
The es was calculated by:

$$
\text { es }=0.611 * 10^{\left[\frac{(7.5 * T a)}{237.3+T a}\right]}
$$

where Ta is the air temperature $\left({ }^{\circ} \mathrm{C}\right)$.

The ea was calculated by:

$$
e a=\frac{(R H * e s)}{100}
$$

where $\mathrm{RH}$ is the relative humidity $(\%)$.

\section{Soil nutrient analysis}

Soil samples were analyzed for $\mathrm{pH}$, phosphorus $(\mathrm{P})$, cation $\left(\mathrm{K}^{+}, \mathrm{Ca}^{2+}, \mathrm{Mg}^{2+}, \mathrm{Al}^{3+}, \mathrm{H}^{+}\right.$, $\mathrm{Zn}^{2+}, \mathrm{Cu}^{2+}, \mathrm{Fe}^{3+}, \mathrm{Mn}^{2+}$, and $\left.\mathrm{B}^{3+}\right)$, and anion $\left(\mathrm{S}^{2-}\right)$ content, organic matter (SOM) and granulometry content using a commercial soil analysis laboratory (Plante Certo, Inc., Várzea Grande, Mato Grosso, Brazil). Briefly, soil $\mathrm{pH}$ was analyzed in distilled water extracts from 1:2.5 soil/extract proportions using a standard $\mathrm{pH}$ meter (TEC - 3MP, TECNAL, Piracicaba, Brazil). The P was analyzed calorimetrically from Mehlich ( $\mathrm{HCl}$ $0,05 \mathrm{~N}+\mathrm{H} 2 \mathrm{SO} 40,0125 \mathrm{~N}$ ) extracts using colorimeter (600s, FEMTO, São Paulo, Brazil) and a flame photometer (B262, Micronal, São Paulo, Brazil), respectively. Soil Ca ${ }^{2+}$, $\mathrm{Mg}^{2+}, \mathrm{Zn}^{2+}, \mathrm{Cu}^{2+}, \mathrm{Fe}^{3+}$ e $\mathrm{Mn}^{2+}$ were analyzed from $1 \mathrm{M} \mathrm{KCl}$ extracts using a flameAtomic Absorption spectrometer (AA1475, Intralab, São Paulo, Brazil). Soil $\mathrm{Al}^{3+}$ and $\mathrm{H}^{+}$were extracted by $0.025 \mathrm{~mol} / \mathrm{L}$ of calcium acetate. The potential acidity was quantified by a manual burette (Vidrolabor, São Paulo, Brazil), using $\mathrm{NaOH} 0.025$ $\mathrm{mol} / \mathrm{L}$ as a titration. Soil organic matter was analyzed calorimetrically using the Walkley-Black method (Nelson and Sommers 1996). Soil CEC was calculated as the sum of all measured cations (Robertson et al. 1999). The particle size distribution was performed by granulometry analysis.

\section{Vegetation structure}

Vegetation structure was characterized at each transect using density calculated as a function of the mean distance and the basal area calculated by converting the circumference into trunk area $\left(\mathrm{m}^{2}\right.$.individual $\left.{ }^{-1}\right)$ and multiplying by the density (individuals. $\mathrm{m}^{-2}$ ) which expresses the dominance (Goldsmith and Harrison, 1976). The index of relative importance (IRI) for each species per transect was calculated as the sum of relative density, dominance, and frequency which was calculated by counting the number of sampling points per transect that a given tree species was observed (Goldsmith and Harrison, 1976). Relative estimates of parameters per transect were calculated for each tree species by dividing the absolute estimates by their respective totals.

Tree species richness within transect was calculated as the number of species encountered per transect, and tree species diversity was calculated using the ShannonWeiner (H') Index (Magurran, 1998). IRI for each species per transect was used to calculate $H^{\prime}$, and confidence intervals $( \pm 95 \%)$ of $H^{\prime}$ were calculated by bootstrapping estimates over 1000 iterations for random sampling with replacement (Efron and Tibshirani, 1993). 


\section{Statistical analyses}

Differences in nutrient concentrations before and after flooding were assessed by comparing mean $\pm 95 \%$ confidence intervals calculated by bootstrapping estimates over 1000 iterations for random sampling with replacement (Efron and Tibshirani, 1993). Simple linear regression was used to test if: (i) the stem diameter affected the tree density, and (ii) V. divergens dominance affected diversity (H'). All statistical analyzes were performed in $\mathrm{R}$ program version 2.15.0 ( $\mathrm{R}$ Core Team 2012).

\section{Results}

\section{Microclimate and flooding}

Lower values of rainfall were in the dry season with no precipitation in July and August (Figure 2a).

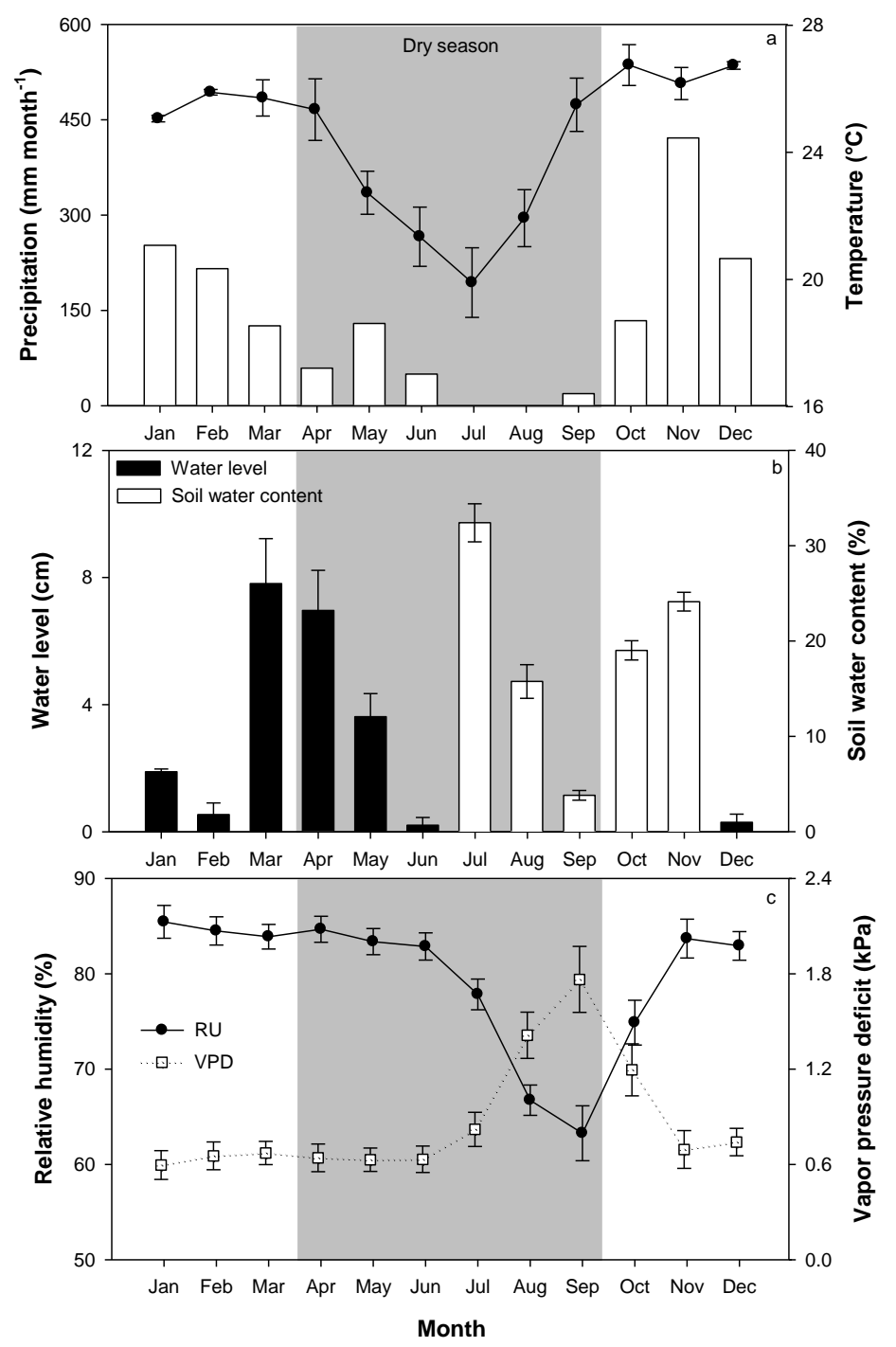

Figure 2. Monthly mean precipitation and temperature (a), water level and water soil content (b), and relative humidity and vapor pressure deficit (c) in a seasonal flooded forest with dominance of Vochysia divergens in the Northern Brazilian Pantanal. Bars represent $\pm 95 \%$ confidence interval. 
The annual precipitation was $1637.91 \mathrm{~mm}$ with $84 \%$ of total amount in the wet season. The annual air temperature was $24.4^{\circ} \mathrm{C}$, with a minimum in July $\left(19.9^{\circ} \mathrm{C}\right)$ and a maximum in December $\left(26.7^{\circ} \mathrm{C}\right)$. The flooding period occurred from January to June and December (Figure 2b). Soil water content followed the seasonal trend in rainfall with the lowest value in September and higher values near the flooding period. Seasonal variation in VPD followed the inverse of seasonal trend in rainfall (Figure 2c). The peak of VPD was in September when was lower values of relative humidity and soil water content.

\section{Seasonal changes in soil properties}

The soil had sandy-clay texture (Figure 3). The concentration of H+Al, H, OM, S, P, $\mathrm{Al}$ and $\mathrm{CEC}$ increased after flooding, but only Fe showed a significant increasing after flooding (Table 1). There was no variation in concentration of $\mathrm{B}$ and $\mathrm{K}$ after flooding. The values of $\mathrm{pH}, \mathrm{Cu}, \mathrm{Zn}, \mathrm{Mg}, \mathrm{Ca}+\mathrm{Mg}$, and sand decreased after flooding, but only values of Mn, clay and silt showed a significant decreasing after flooding.

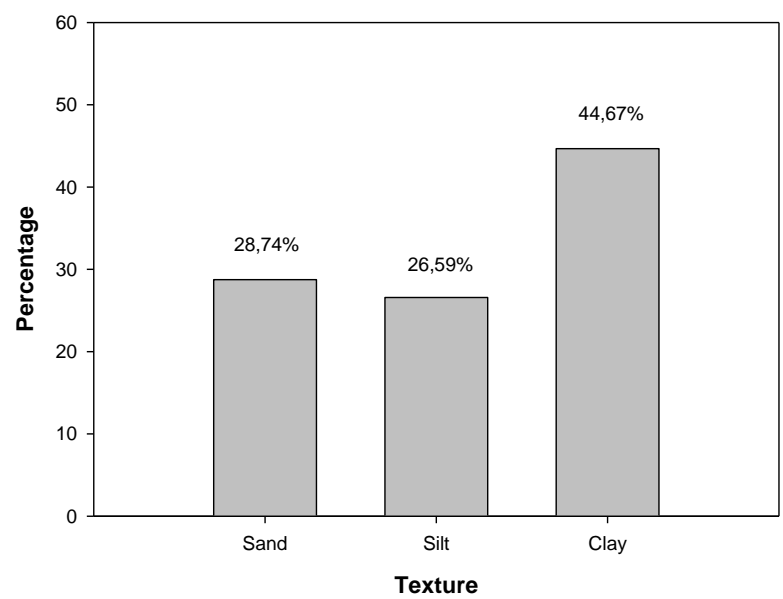

Figure 3. Soil texture in a seasonal flooded forest with dominance of Vochysia divergens in the Northern Brazilian Pantanal.

Table 1. Mean ( $\pm 95 \%$ CI) of nutrient concentration and soil texture before (December/2011) and after (July/2012) flooding and its variation in a seasonal flooded forest with dominance of Vochysia divergens in the Northern Brazilian Pantanal. Values within a row with different uppercase letters are significantly different according to the CI.

\begin{tabular}{|c|c|c|c|}
\hline Variables & Before flooding & After flooding & Seasonal variation $(\%)$ \\
\hline $\mathrm{Fe}(\mathrm{mg} / \mathrm{kg})$ & $165.6 \pm 4.7^{\mathrm{a}}$ & $184.3 \pm 6.5^{\mathrm{b}}$ & 18.7 \\
\hline $\mathrm{H}+\mathrm{Al}(\mathrm{meq} / \mathrm{kg})$ & $45.7 \pm 2.6^{\mathrm{a}}$ & $50.8 \pm 2.7^{\mathrm{a}}$ & 5.1 \\
\hline $\mathrm{H}(\mathrm{meq} / \mathrm{kg})$ & $44.7 \pm 2.7^{\mathrm{a}}$ & $49.2 \pm 2.4^{\mathrm{a}}$ & 4.5 \\
\hline $\mathrm{OM}(\mathrm{g} / \mathrm{kg})$ & $31.7 \pm 2.3^{\mathrm{a}}$ & $35.9 \pm 2.3^{\mathrm{a}}$ & 4.2 \\
\hline $\mathrm{S}(\mathrm{mg} / \mathrm{kg})$ & $17.4 \pm 1.3^{\mathrm{a}}$ & $18.9 \pm 1.3^{\mathrm{a}}$ & 1.5 \\
\hline $\mathrm{P}(\mathrm{mg} / \mathrm{kg})$ & $19.3 \pm 2.8^{\mathrm{a}}$ & $20.7 \pm 3.0^{\mathrm{a}}$ & 1.4 \\
\hline $\mathrm{Al}(\mathrm{meq} / \mathrm{kg})$ & $1.0 \pm 0.4^{\mathrm{a}}$ & $1.5 \pm 0.4^{\mathrm{a}}$ & 0.5 \\
\hline CEC (meq $/ \mathrm{kg})$ & $115.3 \pm 5.6^{\mathrm{a}}$ & $115.7 \pm 4.9^{\mathrm{a}}$ & 0.4 \\
\hline $\mathrm{B}(\mathrm{mg} / \mathrm{kg})$ & $0.3 \pm 0.0^{\mathrm{a}}$ & $0.3 \pm 0.0^{\mathrm{a}}$ & 0.0 \\
\hline $\mathrm{K}(\mathrm{mg} / \mathrm{kg})$ & $0.1 \pm 0.0^{\mathrm{a}}$ & $0.1 \pm 0.0^{\mathrm{a}}$ & 0.0 \\
\hline & $5.3-6.0$ & $5.1-5.9$ & -0.1 \\
\hline
\end{tabular}




\begin{tabular}{lccc}
$\mathrm{Cu}(\mathrm{mg} / \mathrm{kg})$ & $2.1 \pm 0.1^{\mathrm{a}}$ & $2.0 \pm 0.1^{\mathrm{a}}$ & -0.1 \\
$\mathrm{Zn}(\mathrm{mg} / \mathrm{kg})$ & $5.2 \pm 0.4^{\mathrm{a}}$ & $4.9 \pm 0.3^{\mathrm{a}}$ & -0.3 \\
$\mathrm{Mg}(\mathrm{meq} / \mathrm{kg})$ & $19.9 \pm 1.1^{\mathrm{a}}$ & $18.5 \pm 1.1^{\mathrm{a}}$ & -1.4 \\
$\mathrm{Ca}(\mathrm{meq} / \mathrm{kg})$ & $46.8 \pm 2.9^{\mathrm{a}}$ & $43.7 \pm 2.5^{\mathrm{a}}$ & -3.1 \\
$\mathrm{Ca}+\mathrm{Mg}(\mathrm{meq} / \mathrm{kg})$ & $66.5 \pm 4.2^{\mathrm{a}}$ & $62.1 \pm 3.7^{\mathrm{a}}$ & -4.4 \\
$\mathrm{Mn}(\mathrm{mg} / \mathrm{kg})$ & $29.3 \pm 2.5^{\mathrm{a}}$ & $24.0 \pm 1.7^{\mathrm{b}}$ & -5.3 \\
Sand $(\mathrm{g} / \mathrm{kg})$ & $427.9 \pm 11.3^{\mathrm{a}}$ & $409.4 \pm 8.2^{\mathrm{a}}$ & -18.5 \\
Clay $(\mathrm{g} / \mathrm{kg})$ & $428.4 \pm 10.9^{\mathrm{a}}$ & $409.3 \pm 7.8^{\mathrm{b}}$ & -19.1 \\
Silt $(\mathrm{g} / \mathrm{kg})$ & $297.6 \pm 9.4^{\mathrm{a}}$ & $266.7 \pm 15.1^{\mathrm{b}}$ & -30.9 \\
\hline
\end{tabular}

\section{Species composition and vegetation structure}

We found 14 species distributed in 13 families (Table 2). The species with the highest abundance was $V$. divergens followed by $L$. parvifolia and $M$. elliptica. The mean diameter was $28.36 \mathrm{~cm}$, density was 839.98 individuals.ha ${ }^{-1}$, and average basal area was $66.16 \mathrm{~m}^{2} \cdot \mathrm{ha}^{-1}$ (Table 3).

Table 2. Plant species and their abundances in a seasonal flooded forest with dominance of Vochysia divergens in the Northern Brazilian Pantanal.

\begin{tabular}{llcc}
\hline Species & Family & $\begin{array}{c}\text { Absolute } \\
\text { abundance }\end{array}$ & $\begin{array}{c}\text { Relative } \\
\text { abundance (\%) }\end{array}$ \\
\hline Vochysia divergens Pohl & Vochysiaceae & 73 & 33.18 \\
Licania parvifolia Huber. & Chrysobalanaceae & 39 & 17.73 \\
Mouriri elliptica Mart. & Melastomataceae & 34 & 15.45 \\
Alchornea discolor Poepp. \& Endl. & Euphorbiaceae & 28 & 12.73 \\
Ocotea suaveolens Benth. \& Hook.f. ex Hieron. & Lauraceae & 20 & 9.09 \\
Coccoloba ochreolata Wedd. & Polygonaceae & 10 & 4.55 \\
Duroia longiflora Ducke & Rubiaceae & 5 & 2.27 \\
Brosimum lactescens (S. Moore) C.C.Berg & Moraceae & 3 & 1.36 \\
Licania minutiflora Fritsch & Crysobalanaceae & 2 & 0.91 \\
Psidium guineense Sw. & Myrtaceae & 2 & 0.91 \\
Banara arguta Briq. & Flacourtiaceae & 1 & 0.45 \\
Erythroxylum anguifugum Mart. & Erythroxylaceae & 1 & 0.45 \\
Tabebuia serratifolia G. Nicholson & Bignoniaceae & 1 & 0.45 \\
Trichilia catigua A.Juss. & Meliaceae & 1 & 0.45 \\
\hline
\end{tabular}

Table 3. Summary of structural characteristics for transects in a seasonal flooded forest with dominance of Vochysia divergens in the Northern Brazilian Pantanal. All data are mean values except species diversity which is a mean calculated by bootstrap resampling (95\% CI).

\begin{tabular}{cccccc}
\hline Transect & Diameter $(\mathbf{c m})$ & Density $(\# / \mathbf{h a})$ & Basal area $\left(\mathbf{m}^{\mathbf{2}} / \mathbf{h a}\right)$ & Richness & H' \\
\hline A & 23.85 & 1026.53 & 51.88 & 6 & 1.24 \\
B & 29.81 & 635.85 & 61.46 & 6 & 1.35 \\
C & 33.01 & 741.66 & 67.26 & 8 & 1.54 \\
D & 23.79 & 1043.74 & 70.33 & 9 & 1.73 \\
E & 31.35 & 752.11 & 79.87 & 9 & 1.84 \\
\hline
\end{tabular}


The plant community had a negative diameter distribution (Figure $4 a$ ), while the population of $V$. divergens had a Gaussian distribution (Figure $4 b$ ).
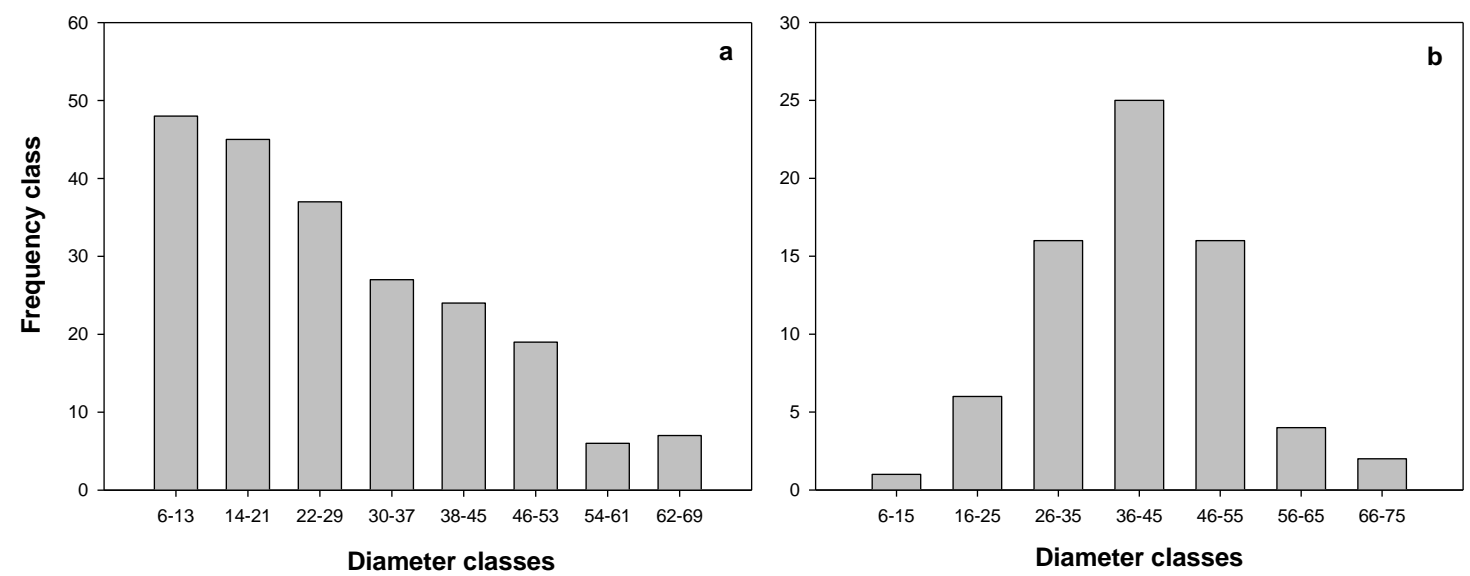

Figure 4. Frequency distribution of stem diameter of plant community (a) and V. divergens population (b) in a seasonal flooded forest with dominance of Vochysia divergens in the Northern Brazilian Pantanal.

The wide distributed species were V. divergens, L. parvifolia, and M. elliptica (Table 4). V. divergens had higher values of IRD and IRI in transects $\mathrm{A}, \mathrm{B}$, and $\mathrm{C}$. $V$. divergens and $A$. discolor had higher values of IRD in the transect $\mathrm{D}$, but $A$. discolor had higher IRI in the transect D. L. parvifolia had higher values of IRD and IRI in the transect E.

Table 4. Plant species and their Index of Relative Density (IRD) and Index of Relative Cover (IRC) along transects in a seasonal flooded forest with dominance of Vochysia divergens in the Northern Brazilian Pantanal.

\begin{tabular}{|c|c|c|c|c|c|c|c|c|c|c|}
\hline \multirow{2}{*}{ Species } & \multicolumn{5}{|c|}{ IRD (\%) } & \multicolumn{5}{|c|}{ IRI (\%) } \\
\hline & $\mathrm{A}$ & $\mathrm{B}$ & $\mathrm{C}$ & $\mathrm{D}$ & $\mathrm{E}$ & A & $\mathrm{B}$ & $\mathrm{C}$ & $\mathrm{D}$ & E \\
\hline A. discolor & 6.8 & & 4.7 & 27.3 & 25.0 & 21.0 & & 11.9 & 118.0 & 71.1 \\
\hline B. arguta & & & & & 2.3 & & & & & 6.0 \\
\hline B. lactescens & & & & 2.3 & 4.5 & & & & 5.9 & 12.4 \\
\hline C. ochreolata & & 13.6 & 7.0 & 2.3 & & & 40.8 & 14.0 & 6.0 & \\
\hline D. ducke & 2.3 & 2.3 & 2.3 & 4.5 & & 6.0 & 5.7 & 5.7 & 11.9 & \\
\hline E. anguifugum & & & 2.3 & & & & & 5.7 & & \\
\hline L. minutiflora & & & & & 4.5 & & & & & 13.4 \\
\hline L. parvifolia & 9.1 & 9.1 & 27.9 & 11.4 & 29.5 & 22.3 & 25.4 & 80.5 & 34.7 & 97.4 \\
\hline M. elliptica & 29.5 & 31.8 & 2.3 & 9.1 & 4.5 & 91.3 & 102.3 & 6.3 & 21.9 & 12.8 \\
\hline O. suaveolens & & 2.3 & 18.6 & 13.6 & 11.4 & & 5.7 & 59.8 & 33.9 & 33.7 \\
\hline P. guineense & & & & & 4.5 & & & & & 12.2 \\
\hline T. serratifolia & & & & 2.3 & & & & & 5.9 & \\
\hline T. catigua & 2.3 & & & & & 6.1 & & & & \\
\hline V. divergens & 50.0 & 40.9 & 34.9 & 27.3 & 13.6 & 153.3 & 120.1 & 116.1 & 61.8 & 41.0 \\
\hline
\end{tabular}


The forest density and diversity decreased with increasing in tree diameter and IRC of $V$. divergens, respectively (Figure $5 a, b$ ).
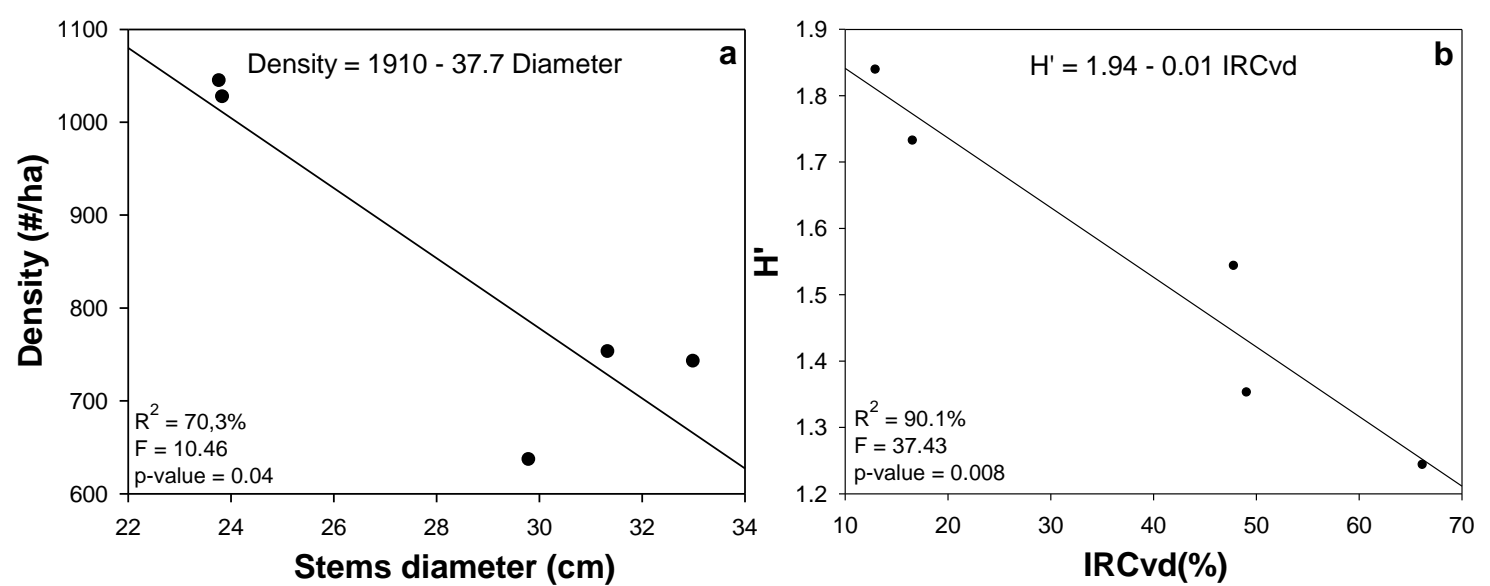

Figure 5. Simple linear regression between density and stems diameter (a), and Diversity Index $\left(H^{\prime}\right)$ and IRCvd (b) in a seasonal flooded forest with dominance of Vochysia divergens in the Northern Brazilian Pantanal.

\section{Discussion}

\section{Hydrometeorological pattern}

The seasonal trend of rainfall was consistent with the climatology for the region. The wet season is from October to March which can represent more than $80 \%$ of the amount of total annual precipitation while low rainfall was recorded during June to September which is consistent with the 4-5-month duration of the dry season (Vourlitis et al., 2008; Biudes et al., 2012; Biudes et al., 2013). Seasonal variation in soil water content (SWC) followed the seasonal trend in rainfall whose soil become saturated in the flooding period from January to June with a peak in March.

The flooding is caused by local rainfall due to the predominant clay texture of the soil and little topographic variation (Penha et al., 1999; Arieira and Nunes da Cunha, 2006). Thus, the flooding period in the Pantanal is a function of rainfall intensity and it can be between 2-8 months (Biudes et al., 2009; Biudes et al., 2013; Arieira et al., 2011). In general, the flooding presents a monomodal pattern with small amplitude (Hamilton et al., 1996).

The air temperature exhibited consistent seasonal trends with lowest values in the dry season when cold air transported by fronts out of the south (friagens) can persist for several days (Grace et al., 1996; Rocha et al., 2009; Biudes et al., 2012). Seasonal variation in vapor pressure deficit (VPD) followed the inverse of seasonal trend in rainfall, air relative humidity and SWC, with higher values in the dry season which is consistent with a variety of tropical forest of Amazon Basin (da Rocha et al., 2004) and Pantanal (Biudes et al., 2013).

\section{Hydrometeorological pattern}

The soil chemical properties varied after flooding as found by Vourlitis et al. (2011) in the Northern Pantanal and Lima et al. (2005) with a lowland soil in an Amazon Forest. The decreasing in concentration of magnesium and calcium was confirmed by 
Vourlitis et al. (2011) and Lima et al. (2005), while increasing of phosphorus and iron was corroborated by Lima et al. (2005), and the $\mathrm{pH}$ reduction by Vourlitis et al. (2011).

Vourlitis et al. (2011) observed variations in soil chemical properties in a forest with dominance of Vochysia divergens, transitional forest, and natural grassland as vegetation types in the Pantanal after flooding, but they pointed out the variations between areas were due to the types of vegetation. However, they recognized that significant space $\mathrm{x}$ time interactions could indicate the spatial dependence of the differences over time. Differences in soil properties between this study and performed by Vourlitis et al. (2011) could be too explained by differences in experimental data collection. While soil samples were collected before and after flooding in this study, Vourlitis et al. (2011) collected soil samples after one year. Thus, their sampled soil suffered the effects of different conditions, such as rain with flooding, drought and rain with no flooding.

Lima et al. (2005) showed in acid soils that phosphates of iron and aluminum are prevalent forms which release phosphorus when the soil $\mathrm{pH}$ increases with flooding. They also pointed out $\mathrm{pH}$ reduction increases with soil by flooding compounds, as they increase the levels of iron and manganese in solution. Moreover, the calcium, magnesium, potassium and sodium were directly influenced by their exchangeable levels as well as by the kinetics of iron and manganese (Lima et al., 2005).

Flooding provokes nutrient transformations which accompany changes in redox potential of soil (Ponnamperuma, 1972; Reddy and Patrick, 1975; Reddy and Patrick, 1976; Buresh et al., 2008; Pezeshki and Delaune, 2012). This happens due to diffusion restriction of atmospheric air to ground, and then oxygen is quickly depleted by breathing of roots and microorganisms, increasing carbon dioxide accumulation (Pezeshki and Delaune, 2012; Reddy and Patrick, 1975; Ponnamperuma, 1972). This accumulation decreases the $\mathrm{pH}$ of alkaline soils, and increases the $\mathrm{pH}$ of acidic soils, resulting in the convergence of the soil $\mathrm{pH}$ between 6.5 and 7 (Kirk, 2004; Ponnamperuma, 1972). The $\mathrm{pH}$ of acidic soils increases because the consumption of hydrogen ions in the reduction processes (Kirk, 2004). However, there are some factors that decrease the $\mathrm{pH}$ in acidic soils, such as: (i) acid soils poor in organic matter reach a $\mathrm{pH}$ below 6.5, (ii) soils rich in sulfides and poor in iron cannot achieve a $\mathrm{pH}$ above 5, and (iii) low temperature and nitrate retard the increase of $\mathrm{pH}$ (Ponnamperuma, 1972).

In general, the organic matter decomposition under anaerobic conditions is slower than under aerobic conditions (Kirk, 2004; Reddy and Patrick, 1975), because the free energy is lower for the reactions involved (Kirk, 2004; Mclatchey and Reddy, 1998). First of all, decomposition involves formation of acids (acetic, propionic and butyric acid), followed by a conversion of the organic acid gases, such as methane (Kirk, 2004). The large amount of clay in the soil reduces the rate of organic matter decomposition in the soil, causing an increase in the amount of soil organic matter (Chapin et al., 2002). Therefore, increasing the organic matter content is a result of the decreased amount of activity of microbial enzymes caused by gradual decrease of microbial biomass due to reduced energy captured by the microorganisms to use an alternative acceptor in their respiration (Mcatchey and Reddy, 1998).

Studies have showed that longer flooding and higher water depth did not follow directly the topographic elevation (Poole et al., 2002; Girard et al., 2010; Fantin-Cruz et al., 2010) probably because it must be related to the transport and deposition of sediments. Longer periods of flooding result in anaerobic conditions for longer (Kirk, 2004) which can result in total loss of more mobile elements, or their precipitation and 
deposition in another part of the profile, in a translocation process, directly influencing pedogenesis of some soils (Lima et al., 2005). Furthermore, it can certainly lead to changes in the absorption of elements by plants, especially those adapted to environments subject to flooding.

\section{Vegetation gradient with dominance of Vochysia Divergens}

All species except Mouriri elliptica, Brosimum lactescens, and Psidium guineense were found by Arieira and Nunes da Cunha (2006) in another sesasonal forest with dominance of Vochysia divergens in the Northern Pantanal. Moreover, Martins et al. (2008) also found the species Vochysia divergens, Erythroxilum anguifugum, and Tabebuia serratifolia in another flooded forest in Brazil. Damasceno-Jr et al. (2005) found $V$. divergens and Alchornea discolor in another flooded forest in Northern Brazilian Pantanal. Nascimento and Nunes da Cunha (1989) found $V$. divergens and $P$. guineense in another flooded forest in Northern Brazilian Pantanal. The number of individuals and species in this study area was smaller than those found by Arieira and Nunes da Cunha (2006), Martins et al. (2008), Damasceno-Jr et al. (2005), and Nascimento and Nunes da Cunha (1989), probably because of the inclusion criteria and sampled method. However, Keogh et al. (1999) pointed out that the area doesn't seem to have a strong effect on species richness in forested wetlands.

The $V$. divergens and $L$. parvifolia create monospecific stands in flooded areas with intermediate depths in the Northern Brazilian Pantanal (Nunes da Cunha et al., 2007), which may explain the greater abundance of these species in our study area. Both species spread rapidly in moist multi-year periods, invading pastures (Nunes da Cunha et al., 2007; Pott and Pott, 1994). However, the expansion of $V$. divergens is controlled by wildfires in drier years (Nunes da Cunha et al., 2007).

The diameter in the study area was greater than found Brito et al. (2008) in a Brazilian seasonal forests, but close to the value found in Everson and Boucher (1998) in an area along Potomac River (USA) and lower than the values found by Baker et al. (2002) in a tropical forest of Ghana, and Pinto-Júnior et al. (2009) in a transitional forest in Brazil. The basal area of the study area was higher than the values found by Campbell et al. (1992) in Brazilian seasonal forests, Klinge et al. (1996) in the Amazon Forest, Pinto-Júnior et al. (2009), Ferreira and Prance (1998) in the Amazon Forest, Ratter et al. (1988) in a semi-deciduous forest of Brazil, and Shanmughavel et al. (2001) in a tropical seasonal forest in China.

The average density of the study area was higher than the values found by Campbell et al. (1992), Ferreira and Prance (1998) in the Amazon Forest, Ratter et al. (1988), Damasceno-Jr. et al. (2005) in a riparian forest in Brazil, Nascimento and Nunes da Cunha (1989) and Arieira and Nunes da Cunha (2006) in monodominant forests in the Northern Brazlian Pantanal, and Shanmughavel et al. (2001) in a seasonal tropical forest in China, but was lower than the values found by Klinge et al. (1996), and Nascimento and Saddi (1992) in a riparian forest in Brazil. Although, the study area has intermediate density compared to other areas, this area showed poorest species composition. The diversity index of Shannon-Wiener in the study area was lower than the values found by Nascimento and Saddi (1992), Campbell et al. (1992), Damasceno-Jr. et al. (2005), and Moreno et al. (2003) in other places.

The forest development is influenced by the self-thinning rule, relating the survival of plants with density dependent mortality in which is the decline of density as the biomass increases with time (Mohler et al., 1978; White, 1981). Therefore, trees with 
smaller diameters are young and with larger are more mature. As a tree grows in a forest, trees begin to compete for light, water and nutrients, causing the death of some trees with intensifying competition (Tang et al., 1994). The frequency distribution of diameters describes the forest development, then the negative distribution indicates young forests and Gaussian-shaped distribution indicates mature forests. Thus, the plant community in the study area is young, while the population of $V$. divergens is transitioning from young trees to mature. Furthermore, the decrease in density with increasing diameter may also be explained by the rule of self-thinning.

The high importance value of a species is influenced by high densities and dominance as showed by $V$. divergens. Arieira and Nunes da Cunha (2006) also found the highest importance values for species $V$. divergens, A. discolor and L. Parvifolia, and the lowest values of importance to L. minutiflora and T. Serratifolia in a seasonally flooded forest in the Pantanal. Damasceno-Jr et al. (2005) also found V. divergens with one of the highest importance value, but the species A. discolor had one of the lowest values of importance. The flooding influences species distribution, working as a stressor for plant communities, or as promoter diversity of habitats and species (Arieira and Nunes da Cunha, 2006), thus being an important factor in the vegetation dynamics in the Northern Brazilian Pantanal. Fantin-Cruz et al. (2010) noted that the distribution of vegetation types was more strongly influenced by flooding aspects and not by the topography. Arieira and Nunes da Cunha (2006) found a positive relationship between $V$. divergens dominance and water level. To better understand these relations is needed to develop studies on the mortality rate, revealing if $V$. divergens as the dominant species is persistent.

The dominance (density or coverage value) for forest stands is determined when a single species compound more than 50\% of the canopy (Connell and Lowman, 1989; Hart et al. 1989). The dominant species was $V$. divergens, and diversity decreased as its dominance increased. Monospecific forests are less diverse than those in which the canopy has no dominance (Connell and Lowman, 1989). The mechanisms that control monodominance are not yet fully known, but may be related to the assumptions based on space or time (Read et al., 2006).

In Central Africa, Torti et al. (2001) proposed that the nutrient return in forests of monospecific Gilbertiodendron dewevrei is retarded by the low decomposition rate of litter preventing the establishment of species with small seeds. Moreover, Peh et al. (2011) argued that the mechanism proposed by Torti et al. (2001) to explain monodominance is not consistent, since their empirical data suggest that soils or soilvegetation interactions are not the cause of the difference in vegetation between mixed and monodominante forest. Arieira and Nunes da Cunha (2006) proposed the flood pulse as a factor affecting the structure and composition of vegetation in a monodominante forest of Vochysia divergens in Northern Pantanal, favoring or limiting the establishment and development of species. Seasonal variations of flooding levels are considered disorders that affect the successional development, allowing pioneer species maintain high densities in the Pantanal (Pott and Pott, 1994; Silva et al., 2000).

\section{Conclusions and Future Research}

These results indicate that (i) flooding affected soil nutrients concentration, and (ii) dominance of Cambará affected species distribution and diversity in the study area. Future research should investigate (i) production, transport and deposition of sediment to understand better the soil nutrient storage in Neotropical seasonal wetlands, and (ii) 
mortality rates of dominant species, revealing if they are persistent which allow a better understanding about the development and establishment of plant species in Neotropical seasonal wetlands.

Acknowledgements. Financial support was provided by Conselho Nacional de Desenvolvimento Científico e Tecnológico - CNPq and Fundação de Amparo à Pesquisa de Mato Grosso - FAPEMAT (286742/2010), and logistic support was provided by Universidade Federal de Mato Grosso - UFMT and Estância Ecológica SESC Pantanal.

\section{REFERENCES}

[1] Amaral Filho, Z.P. (1984): Solos do Pantanal Mato-Grossense. In Anais do $1^{\circ}$ Simpósio sobre recursos naturais e socioeconômicos do Pantanal. EMBRAPA-CPAP-UFMS, 265p. (EMBRAPA-CPAP, Documentos, 5).

[2] Arieira, J.; Nunes da Cunha C. (2006): Fitossociologia de uma floresta inundável monodominante de Vochysia divergens Pohl (Vochysiaceae), no Pantanal Norte, MT, Brasil. - Acta Botanica Brasilica 20 (3): 569-580.

[3] Arieira, J.; Karssenberg, D.; De Jong, S.M.; Addink, E.A.; Couto, E.G.; Nunes da Cunha, C.; Skøien, J.O. (2011): Integrating field sampling, geostatistics and remote sensing to map wetland vegetation in the Pantanal, Brazil. - Biogeosciences, 8, 667-686. doi: 10.5194/bg-8-667-2011.

[4] Baker, T.R.; Affum-Baffo, K.; Burslema, D.F.R.P.; Swaine, M.D. (2002): Phenological differences in tree water use and the timing of tropical forest inventories: conclusions from patterns of dry season diameter change. - Forest Ecology and Management 171: 261-274.

[5] Biudes, M.S.; Nogueira, J.S.; Dalmagro, H.J.; Machado, N.G.; Danelichen, V.H.M.; Souza, M.C. (2012): Mudança no microclima provocada pela conversão de uma floresta de cambará em pastagem no norte do Pantanal. - Revista de Ciências Agro-Ambientais 10 (1): 61-68.

[6] Biudes, M.S.; Campelo-Júnior, J.H.; Nogueira, J.S.; Sanches, L. (2009): Estimativa do balanço de energia em cambarazal e pastagem no norte do Pantanal pelo método da razão de Bowen. - Revista Brasileira de Meteorologia 24(2), 135-143. doi: 10.1590/S010277862009000200003

[7] Biudes, M.S.; Machado, N.G.; Danelichen, V.H.M.; Souza, M.C., Vourlitis, G.L.; Nogueira, J.S. (2013): Ground and remote sensing-based measurements of leaf area index in a transitional forest and seasonal flooded forest in Brazil. - International Journal of Biometeorology (Print). DOI 10.1007/s00484-013-0713-4

[8] Brasil. Ministério do Meio Ambiente, dos Recursos Hídricos e da Amazônia Legal. Plano de Conservação da Bacia do Alto Paraguai (PCBAP): diagnóstico dos meios físico e biótico. Brasília, 1997. 433p.

[9] Brito, E.R.; Martins, S.V.; Oliveira-Filho, A.T.; Silva, E.; Silva, A.F.( 2008): Estrutura fitossociológica de um fragmento natural de floresta inundável em área de Campo Sujo, Lagoa da Confusão, Tocantins. - Acta Amazonica 38 (3): 379-386.

[10] Buresh, R.J. Reddy, K.R.; Kessel, C.V. (2008). Nitrogen transformations in submerged soils. In Nitrogen in agricultural systems. (Eds JS Schepers, WR Raun) Agronomy Monograph 49. pp. 401-436.

[11] Campbell, D.G.; Stone, J.L.; Rosas, J.R.A. (1992): A comparison of the phytosociology and dynamics of three floodplain (Várzea) forests of known ages, rio Juruá, western Brazilian Amazon. - Botanical Journal of the Linnean Society 108: 213-237.

[12] Chapin, F.S.; Matson, P.A.; Vitousek, P.M. (2002): Principles of terrestrial ecosystem ecology. 2nd ed. Springer, New York, 529p. 
[13] Connell, J.H.; Lowman, M.D. (1989): Low-density tropical rain forests: some possible mechanism for their existence. - The American Naturalist 134: 88-119.

[14] da Rocha, H.R.; Manzi, A.O.; Cabral, O.M.; Miller, S.D.; Goulden, M.L.; Saleska, S.R.; Coupe, N.R.; Wofsy, S.C.; Borma, L.S.; Artaxo, P.; Vourlitis, G.; Nogueira, J.S.; Cardoso, F.L.; Nobre, A.D.; Kruijt, B.; Freitas, H.C.; Von Randow, C.; Aguiar, R.G.; Maia, J.F. (2009): Patterns of water and heat flux across a biome gradient from tropical forest to savanna in Brazil. - Journal of Geophysical Research 114(G00B12): 1-8

[15] Damasceno-Junior, G.A.; Semir, J.; Santos, F.A.M.; Leitão-Filho, H.F. (2005): Structure, distribution of species and inundation in a riparian forest of Rio Paraguai, Pantanal, Brazil. - Flora 200 (2): 119-135.

[16] Efron, B.; Tibshirani, R.J. (1993): An introduction to the bootstrap. Chapman \& Hall, New York. p. 443.

[17] Ehhalt, D.; Prather, M.; Dentener, F.; Dlugokencky, E.; Holland, E.; Isaksen, I.; Katima, J.; Kirchhoff, V.; Matson, P.; Midgley, P.; Wang M. Atmospheric chemistry and greenhouse gases. In: Houghton JT, Ding Y, Griggs, D.J.; Noguer, M.; van der Linden, P.J.; Dai, X.; Maskell, K.; Johnson, C.A. (eds) Climate change 2001: the scientific basis. Cambridge University Press, Cambridge, pp 239-287, 2001.

[18] Everson, D.A.; Boucher, D.H. (1998): Tree species-richness and topographic complexity along the riparian edge of the Potomac River. - Forest Ecology and Management 109: 305-314.

[19] Fantin-Cruz, I.; Girard, P.; Zeilhofer, P.; Collischonn, W.; Nunes da Cunha, C. (2010): Unidades fitofisionômicas em mesoescala no Pantanal Norte e suas relações com a geomorfologia. - Biota Neotropica 10 (2): 31-38.

[20] Ferreira, L.V.; Prance, G.T. (1998): Species richness and floristic composition in four hectares in the Jaú National Park in upland forests in Central Amazonian. - Biodiversity and Conservation 7 (10): 1349-1364.

[21] Girard, P.; Fantin-Cruz, I.; Oliveira, S.M.L.; Hamilton, S.K. (2010): Small-scale spatial variation of inundation dynamics in a floodplain of the Pantanal (Brazil). - Hydrobiologia 638(1):223-233.

[22] Goldsmith, F.B.; Harrison, C.M. (1976): Description and analysis of vegetation. In: S.B. Chapman, editor, Methods in plant ecology. Halsted Press, New York. p. 85-156.

[23] Grace, J.; Malhi, Y.; Lloyd, J.; Mcintyre, J.; Miranda, A.C.; Meir, P.; Miranda, H.S. (1996): The Use of Eddy Covariance to Infer the Net Carbon Dioxide Uptake of Brazilian Rain Forest. - Global Change Biology 2, 209-217. doi:10.1111/j.13652486.1996.tb00073.x

[24] Haase, R. (1999): Literfall and nutrient return in seasonally flooded and non-flooded forest of the Pantanal, Mato Grosso, Brazil. - Forest Ecology and Management 117:129147.

[25] Hamilton, S.K. (2002): Hydrological controls of ecological structure and function in the Pantanal wetland (Brazil). The Ecohydrology of South American Rivers and Wetlands. IAHS Special Publication, n. 6.

[26] Hart, T.B.; Hart, J.A.; Murphy, P.G. (1989): Monodominant and species-rich forests in the humid tropics: causes for their co-occurrence. - The American Naturalist 133: 613633.

[27] Junk, W.J.; Nunes da Cunha, C. (2005): Pantanal: A large South American wetland at a crossroads. - Ecological Engineering 24: 391-401. doi:10.1016/j.ecoleng.2004.11.012

[28] Junk, W.J.; Bayley, P.B.; Sparks, R.E. (1989): The flood pulse concept in river floodplain systems. p. 110-127. In: D.P. Dodge (ed.). Proceedings International Large River Symposium (LARS), Canadian Special Publication of Fisheries and Aquatic Sciences, Ottawa, v. 106, p. 110-127, 1989.

[29] Junk, W.J.; Brown, M.; Campbell, I.C.; Finlayson, M.; Gopal, B.; Ramberg, L.; Warner, B.G. (2006): The comparative biodiversity of seven globally important wetlands: A synthesis. - Aquatic Sciences 68 (3): 400-414. 
[30] Junk, W.J.; da Silva, C.J. O Conceito de Pulso de Inundação e suas implicações para o Pantanal de Mato Grosso. 17-28 pp. In: Anais do II Simpósio sobre Recursos Naturais e Sócio-Econômicos do Pantanal: Manejo e Conservação. Corumbá - MS, 1999. Brasília, Embrapa - CPAP.

[31] Keogh, T.M.; Keddy, P.A.; Fraser, L.H. (1999): Patterns of tree species richness in forested wetlands. - Wetlands 19(3): 639-647.

[32] Kirk, G. (2004): The Biogeochemistry of Submerged Soils. John Wiley \& Sons, Chichester.

[33] Klinge, H.; Adis, J.; Worbes, M. (1996): The vegetation of a seasonal várzea in the lower Solimões river, Brazilian Amazonia. - Acta Amazonica 25, 201-220.

[34] Lima, H.N.; Mello, J.W.V.; Schaeffer, C.E.G.R.; Ker, J.C. (2005): Dinâmica da mobilização de elementos em solos da Amazônia submetidos à inundação. - Acta Amazonica 35: 317-330.

[35] Lorenzi, H. (2002): Árvores Brasileiras. v.2. Inst. Plantarum de Estudos da Flora, Ltd., São Paulo, Brasil.

[36] Magurran, A.E. (1998): Ecological diversity and its measurement. Princeton Univ. Press, Princeton NJ. p. 179.

[37] Martins, S.V.M.; Brito, E.R.; Oliveira Filho, A.T.; Silva, A.F.; Silva, E. (2008): Floristic composition of two wetland forests in Araguaian Plain, State of Tocantins, Brazil, and comparison with other areas. - Revista Árvore 32 (1) 129-141.

[38] Mclatchey, G.P.; Reddy, K.R. (1998): Regulation of organic matter decomposition and nutrient release in a wetland soil. - Journal of Environmental Quality 27 (5): 1268-1274.

[39] Mohler, C.L.; Marks, P.L.; Sprugel, D.G. (1978): Stand Structure and Allometry of Trees During Self-Thinning of Pure Stands. - Journal of Ecology 66 (2): 599-614.

[40] Moreno, M.R.; Nascimento, M.T.; Kurtz, B.C. (2003): Estrutura e composição florística do estrato arbóreo em duas zonas altitudinais na Mata Atlântica de encosta da região do Imbê, RJ. - Acta Botanica Brasilica 17(3): 371-386.

[41] Nascimento, M.T.; Nunes Da Cunha, C. (1989): Estrutura e composição florística de um cambarazal no Pantanal de Poconé-MT. - Acta Botanica Brasilica 3(1): 3-23.

[42] Nascimento, M.T.; Saddi, N. (1992): Structure and floristic composition in an area of cerrado in Cuiabá-MT, Brazil. - Revista Brasileira de Botânica 15(1): 47-55.

[43] Neiff, J.J. (1990): Ideas for an ecological interpretation of the Paraná River. - Interciencia 15 (6): 424-441.

[44] Neiff, J.J. (2001): Humedales de la Argentina: sinopsis, problemas y perspectivas futuras. In El Agua en Iberoamerica, Funciones de los humedales, calidad de vida y agua segura (A.F. Cirelli, ed.). CYTED, Argentina, p. 83-112.

[45] Nelson, D.W.; Sommers, L.E. (1996): Total carbon, organic carbon, and organic matter. p. 961-1010. In D.L. Sparks et al. (ed.) Methods of soil analysis: Part 3. Chemical methods. SSSA Book Ser. 5. SSSA, Madison, WI.

[46] Nunes da Cunha, C.; Junk, W.J. (2004): Year-to-year changes in water level drive the invasion of Vochysia divergens in Pantanal grasslands. Applied Vegetation Science 7: 103-110. doi:10.1658/1402-2001(2004)007[0103:YCIWLD]2.0.CO;2

[47] Nunes da Cunha, C.; Junk, W.J. (2001): Distribution of wood plant communities along the flood gradient in the Pantanal of Poconé, Mato Grosso, Brazil. - International Journal of Ecology and Environmental Sciences 27: 63-70.

[48] Nunes da Cunha, C.; Junk, W.J.; Leitão-Filho, H.F. (2007): Woody vegetation in the Pantanal of Mato Grosso, Brasil: a preliminary typology. Amazoniana 19 (3-4): 159-184.

[49] Nunes da Cunha, C.; Junk, W.J. (1999): Composição florística de capões e cordilheiras: localização das espécies lenhosas quanto ao gradiente de inundação no Pantanal de Poconé, MT, Brasil. 387-406. In: Anais do II Simpósio sobre Recursos Naturais e SócioEconômicos do Pantanal - manejo e conservação. Corumbá, MS, 1996. Embrapa - CPAP.

[50] Peh, K.S-H.; Sonké, B.; Lloyd, J.; Quesada, C.A.; Lewis, S.L. (2011): Soil does not explain Monodominance in a Central African Tropical Forest. - PLoS ONE 6(2): 1-9. 
[51] Penha, J.M.; da Silva, C.J.; Bianchini, I. (1999): Productivity of the aquatic macrophytes Pontederia lanceolata Nutt. (Pontederiaceae) on the floodplains of the Pantanal Matogrossense, Brazil. - Wetland Ecology and Management 7: 155-163.

[52] Pezeshki, S.R.; Delaune, R.D. (2012): Soil Oxidation-Reduction in Wetlands and Its Impact on Plant Functioning. - Biology 1: 196-221.

[53] Pinto-Junior, O.B.; Sanches, L.; Dalmolin, A.C.; Nogueira, J.S. (2009): Efluxo de CO2 do solo em floresta de transição Amazônia Cerrado e em área de pastagem. - Acta Amazonica 39 (4): 813-822.

[54] Ponnamperuma, F.N. (1972): The chemistry of submerged soil. Advances in Agronomy 24: 29-96.

[55] Poole, G.C.; Stanford, J.A.; Frissel, C.A.; Running, S.W. (2002): Three-dimensional mapping of geomorphic controls on floodplain hydrology and connectivity from aerial photos. - Geomorphology 48(4): 329-347.

[56] Pott, A.; Pott, V.J. (1994): Plantas do Pantanal. Corumbá, Embrapa - CPAP.

[57] R Core Team. (2012): R: A language and environment for statistical computing. R Foundation for Statistical Computing, Vienna, Austria. ISBN 3-900051-07-0, URL http://www.R-project.org/.

[58] Ratter, J.A.; Pott, A.; Pott, V.J.; Nunes da Cunha, C.; Haridasan, M. (1988): Observations on woody vegetation types in the Pantanal and at Corumbá, Brazil. Notes from the Royal Botanic Garden, Edinburgh 45, 503-525.

[59] Read, J.; Jaffré, T.; Ferris, J.M.; Mccoy, S.; Hope, G.S. (2006): Does soil determine the boundaries of monodominant rain forest with adjacente mixed rain forest and maquis on ultramafic soils in New Caledonia? - Journal of Biogeography 33: 1055-1065.

[60] Rebellato, L.; Nunes Da Cunha, C. (2005): Efeito do "fluxo sazonal mínimo da inundação" sobre a composição e estrutura de um campo inundável no Pantanal de Poconé MT, Brasil. - Acta Botanica Brasilica 19 (4): 789-799.

[61] Reddy, K.R.; Patrick, W.H. (1975): Effect of alternate aerobic and anaerobic conditions on redox potential, organic matter decomposition and nitrogen loss in a flooded soil. Soil Biology and Biochemistry 7 (2): 87-94.

[62] Reddy, K.R.; Patrick, W.H. (1976): Effect of Frequent Changes in Aerobic and anerobic conditions on redox potential and nitrogen loss in a flooded soil. - Soil Biology \& Biochemistry 8: 491-495.

[63] Robertson, G.P.; Coleman, D.C.; Bledsoe, C.S.; Sollins, P. (1999): Standard soil methods for long-term ecological Research. Oxford Univ. Press, New York.

[64] Shanmughavel, P.; Zheng, Z.; Liqing, S.; Min, C. (2001): Floristic structure and biomass distribution of a tropical seasonal rain forest in Xishuangbanna,southwest China. Biomass and Bioenergy 21: 165-175.

[65] Silva, M.P.; Mauro, R.; Mourão, G.; Coutinho, M. (2000): Distribuição e quantificação de classes de vegetação do Pantanal através de levantamento aéreo. - Revista Brasileira de Botânica 23 (2): 143-152.

[66] Sousa, R.O. (2001): Oxirredução em solos alagados afetada por resíduos vegetais. Thesis, Federal University of Rio Grande do Sul, Brazil.

[67] Tang, S.; Meng, C.H.; Meng, F.R.; Wang, Y.H. (1994): A growth and self-thinning model for pure even-age stands: theory and applications. - Forest Ecology and Management 70: 67-73.

[68] Torti, S.D.; Coley, P.D.; Kursar, T.A. (2001): Causes and Consequences of Monodominance in Tropical Lowland Forests. - The American Naturalist 157 (2): 141153.

[69] Vourlitis, G.L.; Lobo, F.A.; Biudes, M.S.; Ortíz, C.E.R.; Nogueira, J.S. (2011): Spatial variations in soil chemistry and organic matter content across a Vochysia divergens invasion front in the Brazilian Pantanal. - Soil Science Society of American Journal 75: 1554-1560. 
[70] Vourlitis, G.L.; Nogueira, J.S.; Lobo, F.A.; Sendall, K.M.; de Faria, J.L.B.; Dias, C.A.A.; Andrade, N.L.R. (2008): Energy Balance and Canopy Conductance of a Tropical SemiDeciduous Forest of the Southern Amazon Basin. - Water Resources Research 44(3), W03412. doi: 10.1029/2006WR005526

[71] White, J. (1981): The Allometric Interpretation of the Self-thinning Rule. Journal of Theoretical Biology 89 (3): 475-500.

[72] Zeilhofer, P. (2006): Soil mapping in the Pantanal of Mato Grosso, Brazil, using multitemporal Landsat TM data. - Wetlands Ecology and Management 14: 445-461.

[73] Zeilhofer, P.; Schessl, M. (2000): Relationship between vegetation and environmental conditions In the Northern Pantanal of Mato Grosso, Brazil. - Journal of Biogeography 27 (1): 159-168. 